\title{
Immune response in rats given irradiated wheat
}

\author{
BY VIJAYALAXMI \\ National Institute of Nutrition, Indian Council of Medical Research, Jamai-Osmania, \\ Hyderabad-500007, India
}

(Received 18 January 1978 - Accepted 2 May 1978)

\begin{abstract}
1. Rats given diets containing freshly-irradiated wheat showed significantly lower mean antibody titres to four different antigens, decreased numbers of antibody-forming cells in the spleen and rosette-forming lymphocytes as compared to rats given either unirradiated wheat or irradiated wheat stored for a period of $\mathrm{I} 2$ weeks.

2. The immune response in rats given $90 \mathrm{~g}$ protein $/ \mathrm{kg}$ diet was essentially similar to that seen in animals given $180 \mathrm{~g}$ protein $/ \mathrm{kg}$ diet.
\end{abstract}

Irradiation has been recommended as one of the methods for disinfestation and prolonged storage of food grains (WHO, 1970). A large number of investigations have so far been carried out which relate to the 'wholesomeness' of irradiated foods. These have included somatic, cytotoxic and mutagenic evaluation. Before the safety of consuming irradiated foods can be fully established, it is essential to determine that when such foods are included in habitual diets, they do not in any way seriously modify vital physiological functions.

Immunological competence is an important host defence mechanism and alterations in this mechanism may be expected to adversely affect resistance to infection. A variety of factors like malnutrition and chemicals are known to modify the immune status (Scrimshaw, Taylor \& Gordon, 1968; Bluestein \& Green, 1970; Nikolaev, Ponomareva, Geller, Rozgan \& Garipova, 1972; Gopalan \& Srikantia, 1973). Also, there is experimental evidence which suggests that several macromolecular dietary components exhibit distinct antigenicity in germ-free animals (Sell, 1964; Wostmann, Pleasants \& Bealmear, 1971). It has been recently reported from this Institute that in children, rats and mice given freshlyirradiated wheat there were evidences of cytotoxicity and mutagenicity, and such changes were not seen when irradiated wheat was stored for 12 weeks before feeding (Bhaskaram \& Sadasivan, 1975; Vijayalaxmi \& Sadasivan, I975; Vijayalaxmi \& Visweswara Rao, 1975; Vijayalaxmi, I976). The present study was designed to investigate the immune response in rats given irradiated wheat as the main ingredient of high $(180 \mathrm{~g} / \mathrm{kg})$ - and marginal $(90 \mathrm{~g} / \mathrm{kg})-$ protein diets. (In poor habitual Indian diets, approximately $80 \%$ of the energy is derived from cereals such as wheat or rice or both, and hence in the present study wheat was incorporated at $700 \mathrm{~g} / \mathrm{kg}$ diet.)

\section{MATERIALS AND METHODS}

In the first study, forty weanling rats of the Wistar strain from the Institute's colony were divided into four groups of five males and five females each. They were maintained on one of the following four diets (protein content $(\mathrm{g} / \mathrm{kg}$ ) in parentheses): unirradiated wheat (I80), unirradiated wheat (90), freshly-irradiated wheat ( $\mathrm{I} 80$ ) and freshly-irradiated wheat (90). The details of the irradiation procedures have been described previously (Vijayalaxmi \& Sadasivan, I975). The composition of the diets is given in Table I.

All rats were immunized I2 weeks after they were started on the experimental diet. At intervals of I week, for a period of three successive weeks, two soluble antigens (tetanus and 
Table I. Composition $(\mathrm{g} / \mathrm{kg})$ of the diets given to rats

\begin{tabular}{|c|c|c|c|c|c|c|}
\hline \multirow[b]{2}{*}{$\begin{array}{r}\text { Dietary protein } \\
\text { content }(\mathrm{g} / \mathrm{kg})\end{array}$} & \multicolumn{2}{|c|}{$\begin{array}{c}\text { Unirradiated } \\
\text { wheat }\end{array}$} & \multicolumn{2}{|c|}{$\begin{array}{l}\text { Freshly- } \\
\text { irradiated } \\
\text { wheat* }\end{array}$} & \multicolumn{2}{|c|}{$\begin{array}{c}\text { Stored } \\
\text { irradiated } \\
\text { wheat } \dagger\end{array}$} \\
\hline & 180 & 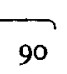 & 180 & $\overrightarrow{90}$ & 180 & 90 \\
\hline Wheat & $70 \cdot 0$ & $70 \cdot 0$ & $70 \cdot 0$ & $70 \cdot 0$ & $70 \cdot 0$ & $70 \cdot 0$ \\
\hline Starch & 9.0 & $20 \cdot 0$ & $9 \cdot 0$ & $20 \cdot 0$ & $9 \cdot 0$ & 20.0 \\
\hline Casein & II O & 一 & II $\cdot O$ & 一 & II $\cdot 0$ & - \\
\hline Refined peanut oil & $5 \cdot 0$ & 5.0 & $5 \cdot 0$ & 5.0 & $5 \cdot 0$ & $5 \cdot 0$ \\
\hline Salt mixture $\ddagger$ & 40 & 40 & 40 & 4.0 & 4.0 & 4.0 \\
\hline Vitamin mixture§ & I. 0 & 1.0 & $I \cdot 0$ & I. 0 & $I \cdot 0$ & $1 \cdot 0$ \\
\hline Choline chloride & 0.1 & 0.1 & 0.1 & $0 . I$ & $0 . I$ & 0.1 \\
\hline
\end{tabular}

* Every $20 \mathrm{~d}$, a fresh batch of irradiated wheat was used to prepare the diet.

+ Irradiated wheat was stored at $10^{\circ}$ for 12 weeks before preparing the diet.

$\ddagger$ Association of Official Analytical Chemists (1965).

$\S$ National Academy of Sciences/National Research Council (1963).

diphtheria), one bacterial antigen (typhoid) and one particulate antigen (sheep red blood cells) were injected into each rat. The following doses were used: $0 \cdot 1 \mathrm{ml}$ tetanus and diphtheria $\left(6 \mathrm{Lf} / \mathrm{ml}\right.$ each) $\left(\mathrm{L}_{F}\right.$ dose of toxin is the appearance of rapid maximal flocculation in the presence of I unit of antitoxin), $0.2 \mathrm{ml}$ typhoid (I000 $\times 10^{6}$ Salmonella typhii $/ \mathrm{ml}$ ) and $0.2 \mathrm{ml}$ sheep red blood cells, $25 \mathrm{ml} / 1$ saline ( $9 \mathrm{~g}$ sodium chloride $/ 1$ ) (washed three times with saline). The soluble and bacterial antigens $(0.3 \mathrm{ml})$ were administered subcutaneously at four different sites, two on the back ( $0.1 \mathrm{ml} / \mathrm{site})$ and two in both foot pads $(0.05 \mathrm{ml} / \mathrm{site})$ while the particulate antigen was injected intraperitoneally.

On the seventh day after final immunization, blood samples were obtained by heart puncture. Sera were separated and stored $-20^{\circ}$ until assayed for antibody titres. Antibodies to tetanus, diphtheria and sheep red blood cells were measured by haemagglutination technique (Tasman, Vanramshorst \& Smith, 1960) while the $\mathrm{H}$ and $\mathrm{O}$ antibodies to typhoid antigen were measured by the standard Widal procedure (Bryan \& Bryan, I96I). In all instances, control tubes were set up using sera from unimmunized rats. The end-point was taken as the greatest serum dilution at which agglutination could be detected by the naked eye. The reciprocal of serum dilution at the end-point was recorded, converted to its logarithm before being subjected to analysis.

In the second study, seventy-two weanling rats of the same strain from the Institute's colony were divided into six groups of six males and six females each and maintained on the four diets described previously, in addition to stored irradiated wheat ( $180 \mathrm{~g}$ protein $/ \mathrm{kg}$ ) and stored irradiated wheat $(90 \mathrm{~g}$ protein $/ \mathrm{kg}$ ). At the end of $\mathrm{I} 2$ weeks on the cooked diet (steamed for $5 \mathrm{~min}$ ), each rat received $\mathrm{I} \mathrm{ml}$ sheep red blood cells $(100 \mathrm{ml} / \mathrm{l}$, washed three times with saline) intraperitoneally and was killed on the fifth day.

Agar plates were prepared in triplicate and the technique of Jerne \& Nordin (1963) was followed for enumeration of antibody-forming cells in the spleen. The method of Wybran, Chantler \& Fudenberg (1973) was followed to determine the rosette-forming lymphocytes $(\%)$. Coded samples were used and 500 consecutive cells were examined for rosette formation, a rosette being defined as a lymphocyte surrounded by at least three sheep red blood cells.

The results were analysed using the two-factor analysis of variance, one factor being irradiation, the other factor was the protein content of the diet. 


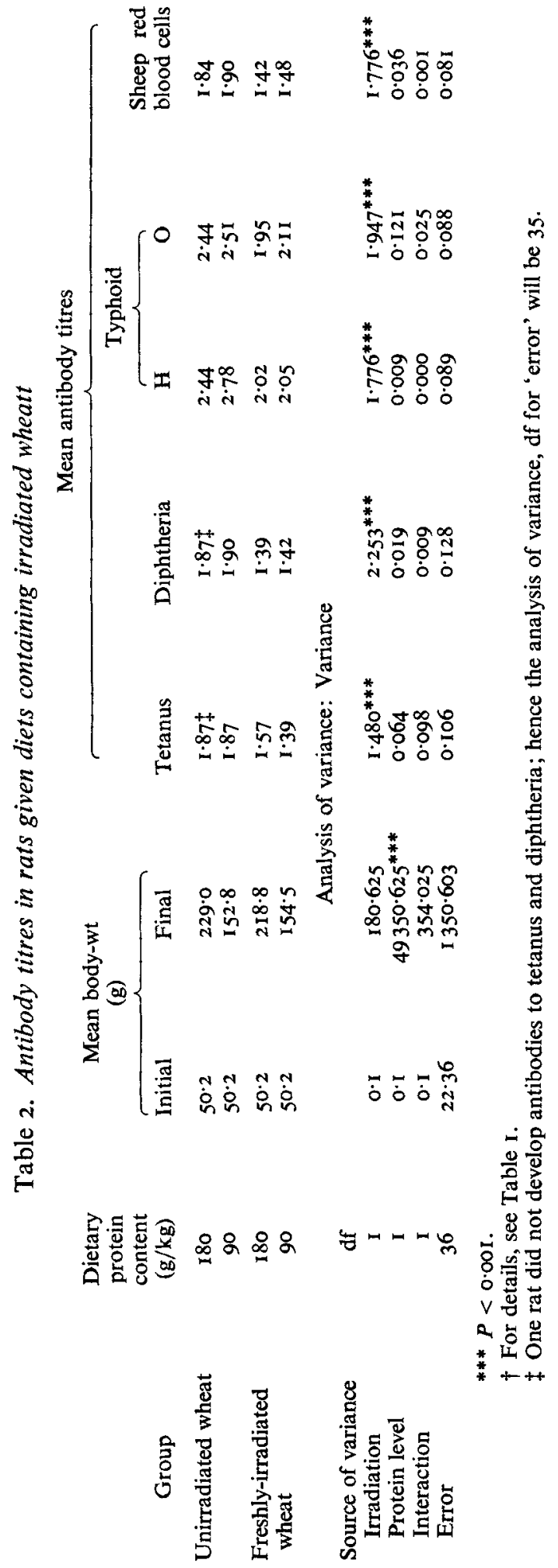


Table 3. Number of rats showing agglutination at different serum dilutions when they were given diets containing irradiated wheat*

(Ten rats/group)

\begin{tabular}{|c|c|c|c|c|c|c|c|c|c|c|c|}
\hline \multirow[b]{3}{*}{ Antigen } & \multirow{3}{*}{ 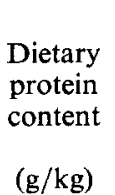 } & \multicolumn{5}{|c|}{ Unirradiated wheat } & \multicolumn{5}{|c|}{ Freshly-irradiated wheat } \\
\hline & & \multicolumn{5}{|c|}{ Serum dilution } & \multicolumn{5}{|c|}{ Serum dilution } \\
\hline & & $1: 5$ & I: 10 & $1: 20$ & $1: 40$ & $1: 80$ & $1: 5$ & I : IO & $I: 20$ & $\mathrm{r}: 40$ & $1: 80$ \\
\hline \multirow[t]{2}{*}{ Sheep red blood cells } & 180 & 10 & 10 & 10 & 9 & 9 & 10 & 9 & 8 & 4 & 3 \\
\hline & 90 & IO & IO & IO & 10 & 10 & 10 & 10 & 8 & 5 & 3 \\
\hline \multirow[t]{2}{*}{ Tetanus } & I $80 \dagger$ & 9 & 9 & 9 & 9 & 8 & I0 & IO & 8 & 6 & 5 \\
\hline & 90 & 10 & 10 & 10 & 10 & 9 & 10 & 8 & 6 & 6 & 3 \\
\hline \multirow[t]{4}{*}{ Diphtheria } & I80t & 9 & 9 & 9 & 9 & 8 & 10 & 8 & 6 & 5 & 4 \\
\hline & 90 & 10 & ro & ro & 10 & ro & IO & 8 & 7 & 6 & 3 \\
\hline & & \multicolumn{5}{|c|}{ Serum dilution } & \multicolumn{5}{|c|}{ Serum dilution } \\
\hline & & $I: 20$ & $I: 40$ & $1: 80$ & I : I 60 & $I: 320$ & $I: 20$ & $1: 40$ & $\mathrm{I}: 80$ & $I: 160$ & $I: 320$ \\
\hline \multirow{3}{*}{$\begin{array}{l}\text { Typhoid: } \\
\text { H }\end{array}$} & & & & & & & & & & & \\
\hline & 180 & IO & I0 & 10 & 10 & 8 & IO & 9 & 7 & 5 & 3 \\
\hline & 90 & 10 & IO & IO & IO & 9 & IO & IO & 7 & 5 & 3 \\
\hline \multirow[t]{2}{*}{0} & I 80 & 10 & 10 & Io & 10 & 8 & 10 & IO & 7 & 5 & 3 \\
\hline & 90 & Io & 10 & 10 & 10 & IO & 10 & IO & 8 & 6 & 3 \\
\hline
\end{tabular}

\section{RESULTS}

The important observations made in these two studies were that at both levels of protein in the diet: (a) rats given freshly-irradiated wheat had significantly lowered mean antibody titres as compared to rats given unirradiated wheat (Table 2$) ;(b)$ the number of rats showing reduced titres increased with increase in serum dilution (Table 3$) ;(c)$ the number of antibody-forming cells as well as rosette-forming lymphocytes was significantly lower in rats given freshly-irradiated wheat as compared to rats given unirradiated and stored irradiated wheat. However, there were no significant differences between unirradiated- and stored irradiated-wheat groups (Table 4).

When the results were analysed to determine the effect of the level of protein in the diet, rats given $\mathrm{I} 80 \mathrm{~g}$ protein $/ \mathrm{kg}$ diet (unirradiated, freshly-irradiated and stored irradiated wheat) showed higher mean body-weight, lower thymus weight and increased number of antibody-forming cells as compared to rats given $90 \mathrm{~g}$ protein $/ \mathrm{kg}$ diet. There were no differences in spleen weight, white blood cell count, lymphocytes $(\%)$, neutrophils, rosetteforming lymphocytes as well as antibody titres.

\section{DISCUSSION}

'Wholesomeness' of irradiated foods has been examined using a variety of criteria but studies undertaken to specifically investigate their effects on the immune system are few. Ehrenberg, Lofroth \& Ehrenberg (1965) and Lofroth, Hanngren, Ehrenberg \& Ehrenberg (1966) have reported lymphopenia in rats given diets irradiated at total doses of 3-9 Mrads, irradiation levels which are several times higher than those recommended by the Joint FAO/IAEA/WHO Expert Committee (1970). Shillinger (1975), however, has reported 

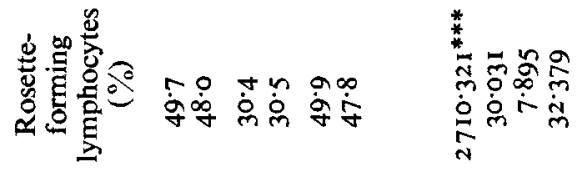

弯.

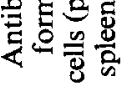

$* *$

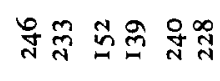

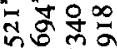

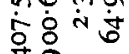

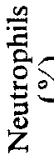

营

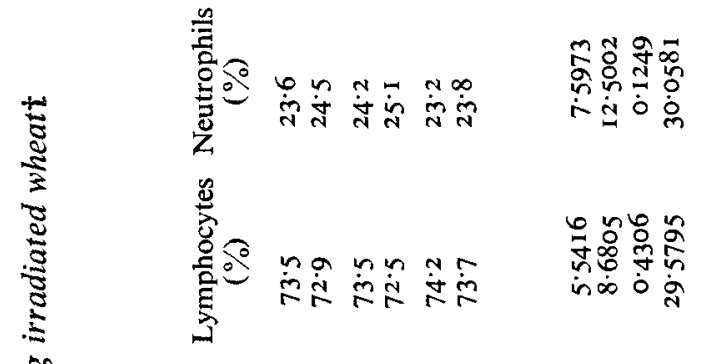

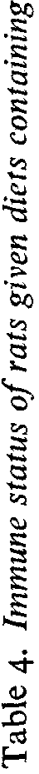

言

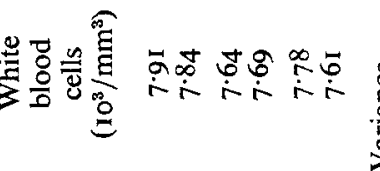

党

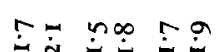

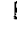

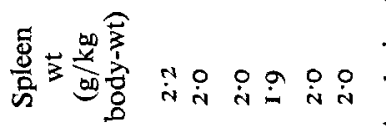

营

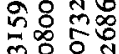

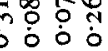

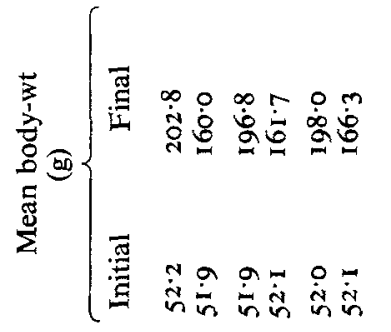

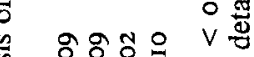

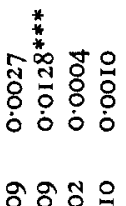

$\stackrel{\dot{0}}{\frac{0}{2}}$ 0

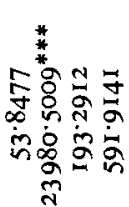

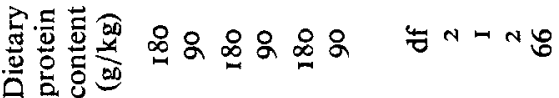

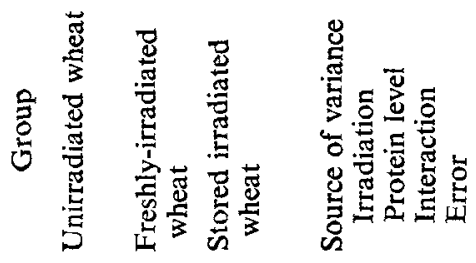


adverse effects on the reproduction function and on the survival rate of young rats of the fifth generation when the dams were given a diet containing irradiated flour, oats (I00 krad), potatoes $(20 \mathrm{krad})$ and meat $(600 \mathrm{krad})$. Furthermore their experimental rats showed a threefold increase in the incidence of pneumonia compared to control animals. They have suggested that this may have been due to reduced resistance in the test rats. Results presented in this paper indicated that at both levels of dietary protein, rats given freshlyirradiated wheat had decreased numbers of antibody-forming cells and rosette forming lymphocytes as well as lowered mean antibody titres as compared to rats given unirradiatedand stored irradiated-wheat diets; observations which may be considered as generally supporting the reports of these earlier workers. It must be emphasized that the irradiation dose used in this study was $75 \mathrm{krad}$, a dose which has been recommended by the Joint FAO/IAEA/WHO Expert Committee (1970).

The observation that antibody titres and rosette-forming lymphocytes in rats maintained on $90 \mathrm{~g}$ protein $/ \mathrm{kg}$ diet were similar to those seen in animals given $\mathrm{I} 80 \mathrm{~g}$ protein $/ \mathrm{kg}$ diet needs explanation, since numerous studies have shown that both humoral and cell-mediated immune responses are reduced in experimental protein-energy malnutrition (Mathur, Ramalingaswami \& Deo, I97I; Gebhardt \& Newberne, 1974; Chandra, 1975). In all these studies the level of protein in the diet was very low, less than $30 \mathrm{~g} / \mathrm{kg}$, whereas in the present investigation the low-protein diet provided $90 \mathrm{~g}$ protein $/ \mathrm{kg}$. It would appear that at $90 \mathrm{~g}$ protein $/ \mathrm{kg}$, the immune response is not impaired. At the time of killing, rats given the $90 \mathrm{~g}$ protein $/ \mathrm{kg}$ diet had a mean body-weight deficit of $30 \%$ as compared to the animals given $\mathrm{I} 80 \mathrm{~g}$ protein $/ \mathrm{kg}$ diet. The finding that they had normal numbers of rosette-forming lymphocytes and could produce satisfactory antibody titres is somewhat similar to the normal humoral and cell-mediated immune responses seen in children whose body-weights were between $70-80 \%$ of the standard (Reddy, Jagadeesan, Raghuramulu, Bhaskaram \& Srikantia, 1976). Results obtained in this study showed that the effect of dietary protein on antibody production and on the antibody-forming cells were somewhat different. This could have been because the former was measured after three repeated injections while the latter were enumerated after primary immunization. The decreased numbers of antibodyforming cells may have been the result of prolonged cell generation time after primary immunization (Mathur et al. 1971).

The mechanism(s) by which the observed effects were brought about are not known. Also the functional significance of the lowered antibody titres, decreased numbers of antibodyforming cells and rosette-forming lymphocytes in rats given freshly-irradiated wheat in relation to increased susceptibility to infection needs further evaluation since it may be argued that although they were low, the antibody titres that were achieved and the number of antibody-forming cells and rosette-forming lymphocytes that were present may have been adequate. It is necessary to carry out in vivo studies to answer this point. Whatever may be the functional significance, results presented in the present paper show that the consumption of irradiated wheat is associated with changes in the immune status of the animal.

The author is deeply indebted to Dr S. G. Srikantia, Director, National Institute of Nutrition, Jamai-Osmania for his keen interest and valuable guidance in this study. The help rendered by Dr N. Raghuramulu, Dr K. Visweswara Rao, Senior Research Officers and Mr A. Nadamuni Naidu, Research Officer, National Institute of Nutrition, is gratefully acknowledged. The technical assistance by Miss $M$. Nirmala is greatly appreciated. 


\section{REFERENCES}

Association of Official Analytical Chemists (1965). Methods of Analysis, Ioth ed., p. 779. Washington, DC: Association of Official Analytical Chemists.

Bhaskaram, C. \& Sadasivan, G. (1975). Am. J. clin. Nutr. 28, 130.

Bluestein, H. G. \& Green, I. (1970). Nature, Lond. 228, 871.

Bryan, A. H. \& Bryan, C. G. (1961). Bacteriology, principles and practices. p. 340. London: Barnes and Noble.

Chandra, R. K. (1975). Science, N.Y. 190, 289.

Ehrenberg, L., Lofroth, G. \& Ehrenberg, A. (1965). Arkiv. Zool. 18, 195.

Gebhardt, B. M. \& Newberne, P. M. (1974). Immunology 26, 489.

Gopalan, C. \& Srikantia, S. G. (1973). Wld Rev. Nutr. Diet. 16, 97.

Jerne, N. K. \& Nordin, A. A. (1963). Science N.Y. 140, 405.

Joint FAO/IAEA/WHO Expert Committee (1970). WHO Tech. Rep. Ser. 45I, 1.

Lofroth, G., Hanngren, K., Ehrenberg, L. \& Ehrenberg, A. (1966). Arkiv. Zool. 18, 529.

Mathur, M., Ramalingaswami, V. \& Deo, M. G. (I97 I). J. Nutr. 102, 84 I.

National Academy of Sciences/National Research Council (1963). Publs Natn Acad. Sci. no. I Ioo, p. 3 I.

Nikolaev, A. I., Ponomareva, L.A., Geller, I. S., Rozgan, M. I. \& Garipova, F. S. (1972). Farmakol. Toksikol. $35,352$.

Reddy, V., Jagadeesan, V., Raghuramulu, N., Bhaskaram, C. \& Srikantia, S. G. (1976). Am. J. clin. Nutr. 29, 3.

Scrimshaw, N. S., Taylor, C. E. \& Gordon, J. E. (I968). WHO Monogr. Ser. no. 57.

Sell, S. (1964). J. Immunol. 93, I 22.

Shillinger (1975). As cited in Fd Irrad. Inf. 5, 52.

Tasman, A., Vanramshorst, J. D. \& Smith, L. (1960). J. Microbiol. Serol. 26, 4I3.

Vijayalaxmi (1976). Can. J. Genet. Cytol. 17, 231.

Vijayalaxmi \& Sadasivan, G. (1975). Int. J. radiat. Biol. 27, 135.

Vijayalaxmi \& Visweswara Rao, K. (1975). Int. J. radiat. Biol. 29, 93.

WHO (I970). Tech. Rep. Ser. Wld Hlth Org. no, 45 I.

Wostmann, B. S., Pleasants, J. R. \& Bealmear, P. (197I). Fedn Proc. Fedn Am. Socs exp. Biol. $30,1779$.

Wybran, J., Chantler, S. \& Fudenberg, H. (I973). Lancet i, I 26. 